\title{
PENDIDIKAN AKHLAK UNTUK MENINGKATKAN KECERDASAN SPIRITUAL ANAK DI RA ULUL ALBAB MANGLI JEMBER
}

\author{
Renda Nur Rofiah \\ Prodi Magister PIAUD UIN Sunan Kalijaga, Jl.Marsda Adisucipto Yogyakarta \\ e-mail: rendanur98@gmail.com
}

\begin{abstract}
This research aimed to investigate the implementation of moral education to develop spiritual intelligence in children aged 4-5 years at Raudlatul Athfal (kindegarten) Ulul Albab Mangli Jember. This type of research was descriptive qualitative research. The results show that the implementation of moral education to develop spiritual intelligence in children aged 4-5 years at RA Ulul Albab Mangli Jember includes planning, implementation, and evaluation. Moral education planning through the preparation of annual programs, semester programs, Weekly Learning Implementation Plans (RPPM), and Daily Learning Implementation Plans (RPPH). Implementation of moral education through exemplary, learning and habituation methods. Evaluation of moral education using assessment sheets and monitoring books. RA Ulul Albab is an institution consistent in developing all aspects of early childhood development, especially spiritual development based on Islamic values and the Standard Level of Child Development Achievement (STPPA).
\end{abstract}

Keywords: moral education, spiritual intelligence, early childhood

\begin{abstract}
ABSTRAK
Penelitian ini bertujuan untuk mengetahui implementasi pendidikan akhlak untuk mengembangkan kecerdasan spiritual pada anak usia 4-5 tahun di RA Ulul Albab Mangli Jember. Jenis penelitian ini adalah penelitian kualitatif deskriptif. Hasil penelitian menunjukkan bahwa Implementasi pendidikan akhlak untuk mengembangkan kecerdasan spiritual pada anak usia 4-5 tahun di RA Ulul Albab Mangli Jember meliputi perencanaan, pelaksanaan, dan evaluasi. Perencanaan pendidikan akhlak melalui penyusunan program tahunan, program semester, Rencana Pelaksanaan Pembelajaran Mingguan (RPPM), dan Rencana Pelaksanaan Pembelajaran Harian (RPPH). Pelaksanaan pendidikan akhlak melalui metode ketauladanan, pembelajaran, dan pembiasaan. Evaluasi pendidikan akhlak menggunakan lembar penilaian dan buku monitoring. RA Ulul Albab merupakan lembaga yang konsisten dalam mengembangkan segala aspek perkembangan anak usia dini khususnya perkembangan spiritual yang berdasarkan nilai-nilai keislaman dan Standart Tingkat Pencapaian Perkembangan Anak (STPPA).
\end{abstract}

Kata Kunci: pendidikan akhlak, kecerdasan spiritual, anak usia dini

\section{PENDAHULUAN}

Saat ini banyak kasus kriminal sering dijumpai melalui berita yang disiarkan melalui media sosial seperti m.liputan6.com, www.kompas.com, news.detik.com atau ditemui secara langsung. 
Kasus kriminal yang sering terjadi diantaranya pencurian, penganiayaan, pembunuhan, dan kasus asusila lainnya. Pelaku dari kasus-kasus tersebut berasal dari beraneka macam golongan, seperti pegawai, mahasiswa bahkan siswa.

Seperti kisah yang terdapat dalam kasus guru kesenian yang meninggal akibat dipukuli di bagian pelipis wajahnya akibat mencoret pipi salah satu siswanya yang mengganggu temantemannya menggunakan tinta. Guru tersebut pingsan kemudian dibawa ke RS. Dr. Soetomo di Surabaya dan dinyatakan meninggal saat dokter mendiagnosa bahwa beliau mengalami mati batang otak dan seluruh organ dalam sudah tidak berfungsi (https://m.liputan6.com). Begitu juga kasus yang sering terjadi di lembaga sekolah baik Sekolah Menengah Atas, Sekolah Menengah Pertama, Sekolah Dasar, maupun Taman Kanak-Kanak. Disana masih banyak ditemui siswa yang bersikap kurang baik, seperti mengambil barang tanpa meminta izin, sering berkelahi antar teman, acuh tak acuh ketika ada orang yang membutuhkan pertolongan.

Kisah tersebut mencerminkan bahwa dunia pendidikan Indonesia sangat memprihatinkan. Oleh karena itu, sangat disayangkan jika generasi penerus bangsa justru menjadi oknum utama yang merusak bangsa sejak usia dini dari segi moral. Adanya pengaruh globalisasi dan kemajuan teknologi yang sangat pesat, turut mempengaruhi gaya hidup, cara berpikir, dan perilaku manusia.

Substansi pendidikan menurut Ki Hajar Dewantara adalah membebaskan manusia dan menurut Drikarya adalah memanusiakan manusia. Ini menunjukkan bahwa para pakar pun menilai bahwa pendidikan tidak hanya sekedar memperhatikan aspek kognitif saja tapi cakupannya harus lebih luas (Nurkholis, 2013: 26).

Sedangkan akhlak merupakan asas pokok bagi umat Islam, sebagaimana diangkatnya Nabi Muhammad sebagai Rasulullah, hanya untuk menyempurnakan akhlak manusia. Karena itu, pendidikan akhlak terhadap anak, menjadi fokus utama dalam Islam. Hal tersebut telah dijelaskan oleh firman Allah SWT dalam Q.S Al-Ahzab (21):

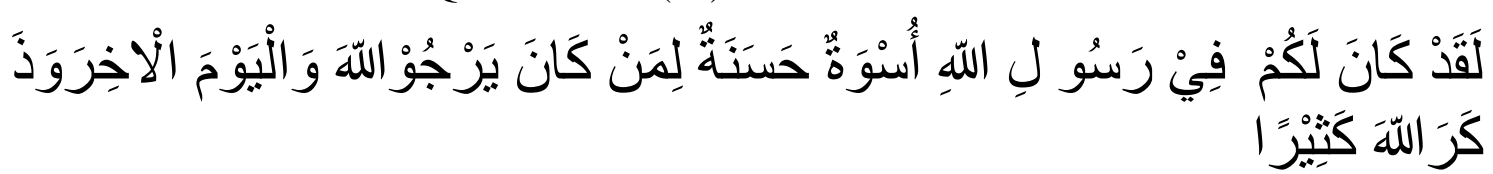

Artinya:Sungguh, telah ada pada (diri) Rasulullah itu suri tauladan yang baik bagimu (yaitu) bagi orang yang mengharap (rahmat) Allah dan (kedatangan) hari Kiamat dan yang banyak mengingat Allah.

Melalui Q.S. Al-Ahzab (21) dapat kita pahami bahwa kepribadian dalam diri Rasulullah SAW merupakan hal-hal yang patut diteladani. Hal ini sejalan dengan pendapat Quraisy Syihab dalam tafsir al-Misbah, soal-soal agama keteladanan merupakan kewajiban tetapi soal-soal keduniaan ia merupakan anjuran (Anica, 2017: 90).

Al-Ghazali mendefnisikan akhlak adalah sebagai berikut: 


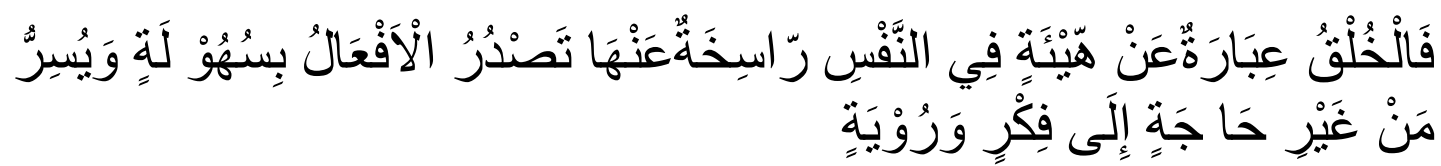

Artinya : "Akhlak ialah suatu sifat yang tertanam dalam jiwa yang dari padanya timbul perbuatan-perbuatan dengan mudah dengan tidak memerlukan pertimbangan pikiran (lebih dahulu)".

Dari pendapat di atas dapat dipahami bahwa akhlak adalah sifat yang tertanam dalam jiwa manusia, sehingga akan menimbulkan berbagai macam perbuatan secara spontan dan tanpa memerlukan pertimbangan terlebih dahulu.

Dari pengertian di atas dapat disimpulkan bahwa pendidikan akhlak adalah proses mendidik, memelihara, membentuk, memberikan latihan mengenai akhlak dan kecerdasan berfikir baik secara formal maupun informal yang didasarkan pada ajaran-ajaran agama Islam (Abdullah, 2007: 23). Oleh karena itu sangat diperlukannya pendidikan akhlak sejak dini untuk membentuk pribadi manusia menjadi manusia seutuhnya. Pendidikan akhlak pada anak usia dini merupakan wahana pembinaan manusia menuju sosok yang berakhlak terpuji, bermoral baik, dan beriman serta bertaqwa kepada Allah SWT. Pada usia dini anak mengalami masa golden age dan sangat tepat untuk meletakkan dasar-dasar pengembangan kemampuan anak terutama mengenai akhlak. Nilai-nilai akhlak yang ditanamkan sejak dini akan berkontribusi terhadap perilakunya di masa yang akan datang. Pendidikan akhlak yang ditanamkan sejak dini dapat membentuk anak-anak sebagai benih bangsa yang diharapkan akhirnya hadir sebagai sosok utuh yang memberi manfaat bagi agama, nusa, dan bangsa.

RA Ulul Albab Mangli Jember dipilih sebagai tempat penelitian tentang implementasi pendidikan akhlak untuk anak usia 4-5 tahun karena memiliki alasan yang kuat diantaranya: RA Ulul Albab merupakan sekolah yang tidak hanya mengedepankan pengembangan potensi anak di bidang intelektual akademik, melainkan juga membimbing dan membentuk kepribadian anak yang memiliki integritas spiritual dibuktikan oleh visi RA Ulul Albab yang berbunyi "Menjadi Lembaga Pendidikan Anak Usia Dini Berkarakter Islami, Cerdas, dan Mandiri”. Kedua, RA Ulul Albab adalah salah satu lembaga pendidikan Islam unggulan di Kabupaten Jember yang berada di naungan Yayasan Pendidikan Islam Ulul Albab terbukti dari banyaknya prestasi tingkat local dan nasional yang pernah diraih serta penghargaan yang diberikan oleh Bupati Kabupaten Jember kepada RA Ulul Albab. Ketiga, RA Ulul Albab merupakan sekolah yang konsisten mengimplementasikan pendidikan akhlak dengan berbagai metode terbukti dengan karakter islami yang muncul dari peserta didiknya diantara lain anak terbiasa menggunakan kata ajaib (maaf, tolong, permisi, terimakasih) dalam kehidupan sehari-hari.

Implementasi pendidikan akhlak untuk meningkatkan kecerdasan spiritual anak usia 4-5 tahun di RA Ulul Albab Mangli Jember melalui beberapa tahapan yaitu perencanaan, pelaksanaan, dan evaluasi. 
Perencanaan pembelajaran merupakan suatu rangkaian terkait dengan prosedur-prosedur penentuan yang dilakukan pada saat proses pembelajaran berlangsung agar dapat mencapai tujuan pembelajaran yang diinginkan. Hal ini diperkuat dengan pendapat Abdul Majid yaitu, perencanaan adalah mengandung rangkaian-rangkaian putusan yang luas dan penjelasan-penjelasan dari tujuan pembelajaran, penentuan kebijakan, serta penentuan kegiatan berdasarkan jadwal sehari-hari (Majid, 2007: 15-16).

Ibnu Maskawaih menjelaskan bahwa pelaksanaan pendidikan akhlak akan mampu menuntun anak-anak remaja menjadi manusia dewasa dalam arti; dewasa secara sosial, emosional dan intelektual serta memiliki sikap kepribadian sebaik yang ditunjukkan Al-Qur'an dan hadits Rasulullah SAW (Sudarsono, 2005: 151).

Tahap terakhir yaitu evaluasi pendidikan akhlak. Evaluasi merupakan bagian yang sangat penting dalam proses pendidikan. Evaluasi merupakan proses sistematis untuk memperoleh informasi tentang tingkat keefektifan proses pembelajaran secara optimal (Komsiyah, 2012: 110). Pada tahap evaluasi yang dikerjakan adalah melakukan evaluasi terhadap perubahan atau perbaikan terhadap program yang sudah direncanakan. Kemudia pada tahap ini mengecek seberapa besar pengaruh program yang sudah direncanakan (Sufi, 2018: 53).

\section{METODE PENELITIAN}

Penelitian ini menggunakan jenis penelitian kualitatif deskriptif. Penelitian dengan pendekatan kualitatif ini bersifat luwes, tidak terlalu rinci, tidak lazim mendefinisikan suatu konsep, serta memberi kemungkinan bagi perubahan-perubahan manakala ditemukan fakta yang lebih mendasar, menarik, dan unik bermakna di lapangan (Bungin, 2008: 39). Penelitian kualitatif ini fokus rancangannya yaitu fokus penelitian yang harus digali secara mendalam dan tuntas dari beberapa dimensi-dimensi yang menjadi pusat perhatian.

Adapun jenis penelitian yang digunakan adalah deskriptif, yaitu penelitian yang berusaha mendeskripsikan suatu gejala, peristiwa, dan kejadian yang terjadi. Penelitian deskriptif mempelajari masalah-masalah dalam masyarakat serta situasi-situasi tertentu, termasuk tentang hubungan kegiatan-kegiatan sikap, pandangan,-pandangan serta proses yang sedang berlangsung dan pengaruh-pengaruh dari suatu fenomena (Sudjana, 2001: 64).

Penelitian ini dilakukan pada bulan Maret 2020 sampai selesa. Penelitian ini dilaksanakan di RA Ulul Albab Mangli, Jember. Adapun teknik pengumpulan data yang digunakan adalah sebagai berikut wawancara, dokumentasi, dan observasi.

\section{HASIL DAN PEMBAHASAN}

Berdasarkan data yang diperoleh pendidikan akhlak diartikan sebagai usaha yang dilakukan pendidik kepada anak didik dalam upaya pembinaan nilai-nilai akhlak yang luhur, baik 
terhadap Allah SWT, manusia, maupun lingkungan melalui latihan mental dan fisik mengenai akhlak baik bersifat formal maupun informal yang didasarkan pada ajaran-ajaran Islam.

Dalam penerapan pendidikan akhlak untuk meningkatkan kecerdasan spiritual pada anak usia 4-5 tahun di RA Ulul Albab, ada beberapa langkah yang digunakan. Pertama, perencanaan pendidikan akhlak. Kedua, pelaksanaan pendidikan akhlak. Ketiga, evaluasi pendidikan akhlak.

Berdasarkan hasil temuan penelitian dapat diketahui bahwa perencanaan pendidikan akhlak untuk meningkatkan kecerdasan spiritual pada anak usia 4-5 tahun di RA Ulul Albab Mangli, Jember antara lain tim guru menyiapkan program tahunan, program semester, materi pembelajaran serta guru kelas menyusun RPPH (Rencana Pelaksanaan Pembelajaran Harian) yang isinya berpacu pada kurikulum 2013.

Program tahunan maupun program semester yang dilakukan sekolah untuk mendukung pendidikan akhlak yang diterapkan di sekolah tersebut juga disusun di awal tahun dan di awal semester. Program-program tersebut diantaranya, Jum'at beramal, parenting, infaq rutin setiap hari.

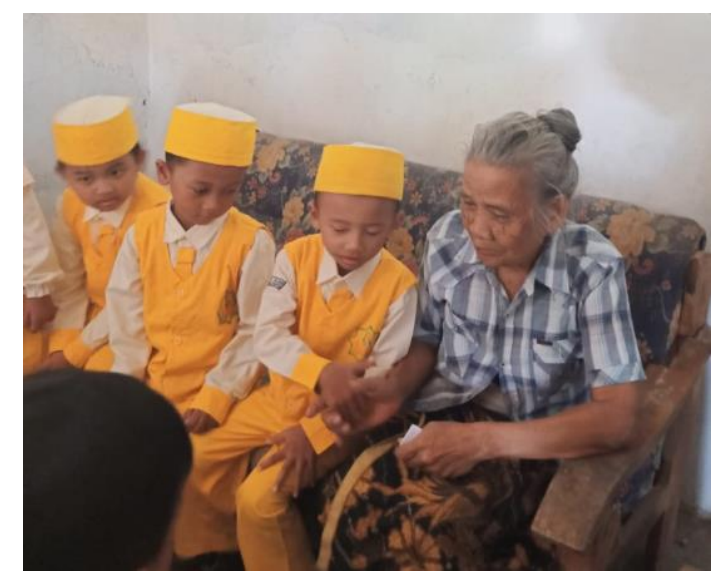

Gambar 1. Kegiatan Jum'at beramal di salah satu rumah lansia

Temuan tersebut memperkuat teori Majid (2007: 15-16) bahwa perencanaan pembelajaran merupakan suatu rangkaian terkait dengan prosedur-prosedur penentuan yang dilakukan pada saat proses pembelajaran berlangsung agar dapat mencapai tujuan pembelajaran yang diinginkan. Hal ini diperkuat dengan pendapat Abdul Majid yaitu, perencanaan adalah mengandung rangkaianrangkaian putusan yang luas dan penjelasan-penjelasan dari tujuan pembelajaran, penentuan kebijakan, serta penentuan kegiatan berdasarkan jadwal sehari-hari.

Tahap selanjutnya yaitu pelaksanaan. Pada tahap ini pelaksanaan pendidikan akhlak pada anak usia 4-5 tahun di RA Ulul Albab menggunakan beberapa cara, yaitu melalui ketauladanan, pembelajaran, dan pembiasaan. Berbagai cara tersebut dilakukan untuk membina peserta didik agar memiliki sikap yang baik sesuai dengan STPPA Anak Usia 4-5 tahun dalam aspek perkembangan Nilai Agama dan Moral. 
Temuan tersebut sejalan dengan pendapat Ibnu Maskawaih, tujuan pembinaan akhlak yaitu terwujudnya sikap batin yang mampu mendorong secara spontan untuk melahirkan semua perbuatan yang bernilai baik, sehingga mencapai kesempurnaan dan memperoleh kebahagiaan sejati dan sempurna. Jadi, tujuan pembinaan akhlak yang ingin dicapai oleh Ibn Miskawaih bersifat menyeluruh yakni mencakup kebahagiaan hidup manusia dalam arti yang seluas-luasnya. ${ }^{1}$

Ketualadanan yang dimaksud adalah contoh yang diberikan pendidik kepada peserta didik tentang perilaku yang baik. Misalnya, ketika sampai di sekolah guru satu dengan guru lainnya akan bertukar salam dan bersalaman. Hal ini menjadi contoh untuk peserta didik. Peserta didik juga akan menerapkan hal yang sama ketika sampai di sekolah. Mereka akan mengucapkan salam dan bersalaman dengan guru piket.

Selain ketauladan, dalam proses pembelajaran juga diterapkan nilai-nilai akhlak terpuji. Pembelajaran dibagi menjadi tiga bagian yaitu kegiatan pembukaan, kegiatan ini, dan kegiatan penutup. Pada kegiatan pembukaan, proses pembelajaran dilaksanakan dengan metode klasikal. Seluruh siswa dikumpulkan dalam satu ruangan dan diberikan materi yang sama. Materi yang diberikan berupa hafalan surat-surat pendek, do'a harian, dan lagu-lagu sesuai tema. Selain materi tersebut, ada pembiasaan yang dilakukan sesuai jadwal yang sudah ditentukan.

Pada hari Senin, pembiasaan yang dilakukan adalah upacara bendera, pada hari Selasa pembiasaan yang dilakukan adalah Sholat Dhuha berjamaah, pada hari Rabu dan Kamis pembiasaan yang dilakukan adalah senam bersama. Dan pada hari Jum'at pembiasaan yang dilakukan adalah i'tiraf dengan membaca asmaul husna serta shalawat nariyah. Setelah kegiatan pembukaan, peserta didik diarahkan masuk ke dalam kelas masing-masing untuk mengikuti kegiatan inti.

Kegiatan pembelajaran di RA Ulul Albab menggunakan sistem pembelajaran berbasis multiple intelegence. Materi yang diberikan sesuai dengan buku materi karya tim guru RA Ulul Albab yaitu berupa materi pembelajaran berbasis multiple intelegence yang berpedoman pada kurikulum 2013. Ruang kelasnya pun juga berupa lab pembelajaran. Di RA-A ada enam lab yaitu lab naturalis, lab kinestetik, lab agama, lab linguistik, lab visual, dan lab logika-matematika. Di dalam kegiatan lab tidak ada kegiatan khusus tentang pendidikan akhlak. Akan tetapi nilai-nilai akhlak masuk ke dalam indikator yang harus dicapai sesuai dengan aspek perkembangan anak usia dini, yaitu pada aspek NAM dan sosial-emosional. Misalnya, peserta didik mampu menghargai diri sendiri, orang lain dan lingkungan sekitar sebagai rasa syukur kepada Tuhan, peserta didik memiliki perilaku yang mencerminkan sikap taat terhadap aturan sehari-hari, peserta didik mampu bersikap sopan dan peduli melalui perkataan dan perbuatannya.

Selain melalui indikator tersebut, praktik di lapangan yang dilakukan oleh guru kelas RAA untuk membentuk kepribadian perserta didik yang baik yaitu dengan cara pembiasaan yang baik

\footnotetext{
${ }^{1}$ Muhammad Azmi, Pembinaan Akhlak Anak Usia Dini Pra Sekolah (Jogjakarta: Belukar, 2006),, 60.
} 
ketika proses pembelajaran. Misalnya, peserta didik dibiasakan meletakkan kembali peralatan belajar sesuai tempatnya, peserta didik dibiasakan antri dalam berbagai hal. Kemudian, jika sudah selesai kegiatan inti di dalam kelas peserta didik diberi waktu 30 menit untuk beristirahat. Kegiatan istirahat yang biasa dilakukan yaitu memakan bekal yang sudah dibawa dari rumah dan bermain bersama teman-teman. Setelah itu, peserta didik masuk ke dalam kelas lagi untuk mengikuti kegiatan penutup. Kegiatan penutup diisi dengan pengulangan materi yang sudah diberikan mulai awal sampai akhir pembelajaran.

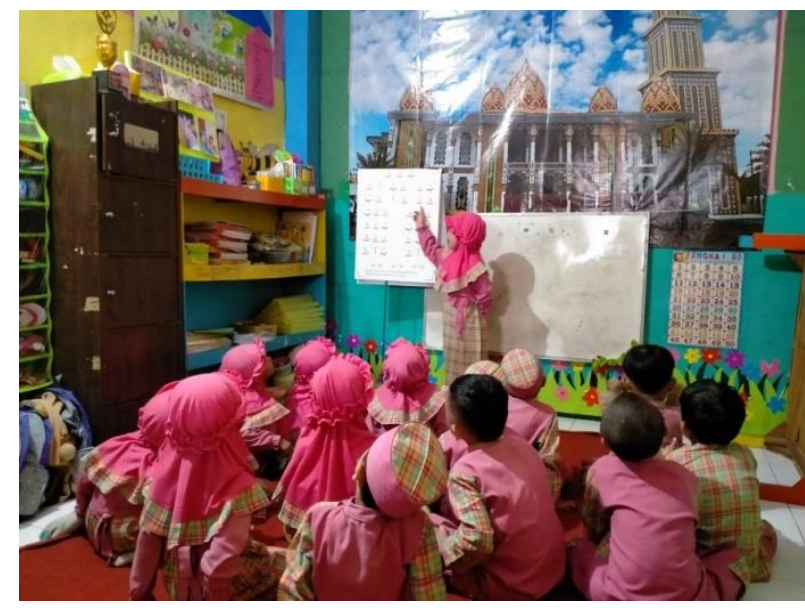

Gambar 2. Kegiatan pembelajaran di dalam kelas

Cara terakhir yang digunakan dalam implementasi pendidikan akhlak di RA Ulul Albab yaitu melalui pembiasaan. Pembiasaan yang dimaksud adalah berupa perilaku yang diulang-ulang secara terus-menerus. Melalui pembiasaan, peserta didik akan terbiasa bersikap baik dengan tanpa paksaan. Pembiasaan yang dilakukan yaitu berdo'a sebelum dan sesudah melakukan sesuatu, pembiasaan menggunakan kata ajaib (maaf, tolong, permisi, terima kasih), menolong orang lain, antri ketika mencuci tangan dan membeli makanan di kantin sekolah, membuang sampah pada tempatnya. Menurut pendidik dan wali murid pembiasaan merupakan cara yang efektif untuk implementasi pendidikan akhlak.

Temuan tersebut sejalan dengan pandangan Marzuki (2019: 23) dijelaskan bahwa. Akhlak atau pendidikan karakter tidak hanya mengajarkan mana yang benar dan mana yang salah kepada peserta didik, tetapi juga menanamkan kebiasaan (habituation) tentang yang baik sehinga peserta didik paham, mampu merasakan, dan mau melakukannya. Dengan demikian pendidikan karakter membawa misi yang sama dengan pendidikan akhlak atau pendidikan moral.

Tahap selanjutnya yaitu evaluasi. Berdasarkan hasil temuan menunjukkan bahwa evaluasi pendidikan akhlak untuk meningkatkan kecerdasan spiritual anak usia 4-5 tahun di RA Ulul Albab menggunakan beberapa cara yaitu lembar penilaian berupa ceklist dan catatan anekdot. Penilaian yang dimaksud berbeda dengan penilaian pada jenjang pendidikan lainnya. Pada jenjang pendidikan Sekolah Dasar (SD), Sekolah Menengah Pertama (SMP), maupun Sekolah Menengah 
Pertama (SMA) penilaian bisa dilakukan dengan angka. Tetapi, berbeda halnya dengan penilaian pada jenjang usia 4-5 tahun.

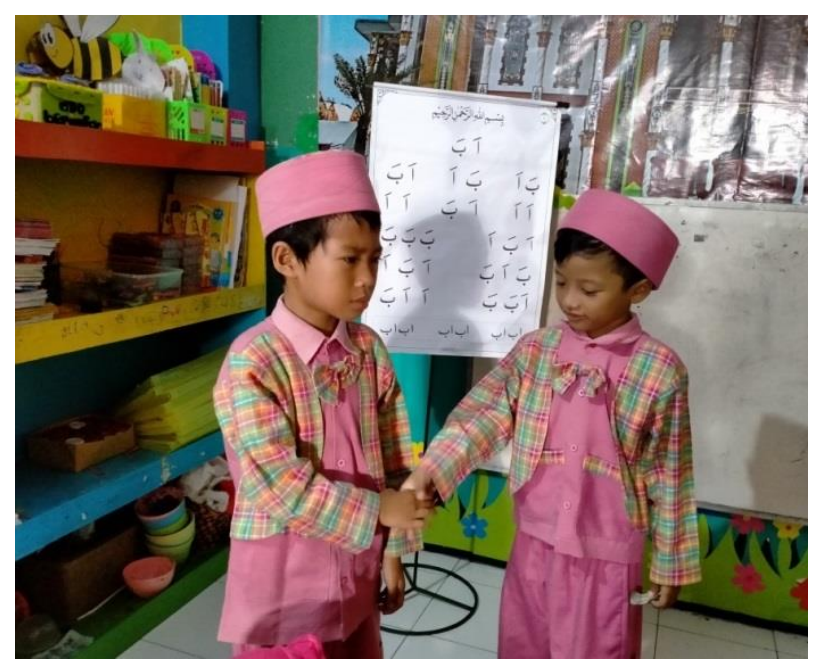

Gambar 3. Pembiasaan meminta maaf ketika salah

Di RA Ulul Albab, penilaian berupa ceklist dan deskriptif. Penilaian ceklist berupa lembar penilaian ceklist, dan dekripsinya berupa catatan anekdot. Indikator yang digunakan berpedoman pada Standart Tingkat Pencapaian Perkembangan Anak (STPPA) Usia 4-5 Tahun Kurikulum 2013. Jika ada perubahan perilaku pada peserta didik, hal tersebut akan dideskripsikan pada catatan anekdot. Catatan anekdot dan ceklist dilakukan secara bertahap. Setiap hari pendidik bertugas menilai perkembangan kognitif, afektif, maupun psikomotorik peserta didik melalui observasi secara langsung.

Selain itu, media lain yang dapat dilakukan untuk melakukan evaluasi pendidikan akhlak di RA Ulul Albab yaitu buku penghubung. Dalam buku penghubung terdapat laporan perkembangan anak selama di sekolah. Di sana juga terdapat kolom komentar untuk orang tua. Kolom tersebut biasanya diisi dengan penjelasan orang tua tentang sikap anak selama di rumah. Jika ada perbedaan sikap peserta didik ketika berada di sekolah dan berada di rumah, maka hal tersebut akan ditindaklanjuti oleh guru kelas dan kepala sekolah. Dari pelaksanaan pendidikan akhlak yang diterapkan secara konsisten, hal tersebut disimpulkan cukup efektif untuk meningkatkan kecerdasan spiritual anak usia 4-5 tahun sesuai dengan Standart Tingkat Pencapaian Anak (STPPA) Usia 4-5 tahun Kurikulum 2013.

Temuan tersebut sejalan dengan temuan Fauzi Sufi (2018: 53) bahwa pada tahap evaluasi yang dikerjakan adalah melakukan evaluasi terhadap perubahan atau perbaikan terhadap program yang sudah direncanakan. Kemudian pada tahap ini mengecek seberapa besar pengaruhnya program yang sudah direncanakan. 


\section{KESIMPULAN}

Sesuai dengan Standart Tingkat Pencapaian Perkembangan Anak (STPPA) usia 4-5 tahun PAUD Kurikulum 2013, kecerdasan spiritual masuk ke dalam aspek perkembangan Nilai Agama dan Moral (NAM). Sehingga, perencanaan pendidikan akhlak untuk meningkatkan kecerdasan spiritual juga disesuaikan dengan pedoman tersebut.

Kemudian, pelaksanaan pendidikan akhlak untuk meningkatkan kecerdasan spiritual pada anak usia 4-5 tahun di RA Ulul Albab Mangli, Jember Tahun Ajaran 2019/2020 menggunakan beberapa metode sesuai dengan visi misi sekolah tersebut. Yaitu melalui ketauladanan, pembiasaan, dan pembelajaran. Pelaksanaan pendidikan akhlak dilakukan dengan konsisten secara bertahap. Pada mulanya, pendidik memberikan contoh bersikap baik serta sebagai tauladan peserta didik ketika berada di sekolah, Sehingga, pelaksanaan pendidikan akhlak dapat dievaluasi melalui lembar penilaian berupa ceklist dan catatan anekdot dalam proses pembelajaran. Selain itu, media yang digunakan berupa buku monitoring anak untuk menjaga komunikasi sekolah dengan orang tua terkait perkembangan peserta didik.

Pendidikan akhlak yang diterapkan secara konsisten dapat disimpulkan bahwa melalui metode yang digunakan cukup efisien untuk meningkatkan kecerdasan spiritual anak usia 4-5 tahun di RA Ulul Albab.

\section{SARAN}

1. Kepala Madrasah

Agar senantiasa berupaya untuk mengontrol pelaksanaan pendidikan akhlak yang diterapkan oleh guru khususnya sehingga kecerdasan spiritual anak tetap berkembang, serta menjaga kerjasama yang baik dengan para pendidik dan orang tua peserta didik untuk melaksanakan pendidikan akhlak khususnya yang berkaitan dengan kecerdasan spiritual anak.

2. Dewan Guru

Dapat melaksanakan pendidikan akhlak dengan baik, maka sebagai tenaga pendidik haruslah melaksanakannya secara obyektif dan berkelanjutan, dan menjalin kerjasama yang baik antar sesama pendidik, peserta didik, orang tua peserta didik dan juga masyarakat dalam meningkatkan kecerdasan spiritual anak guna dapat mencapai sebuah tujuan yang telah ditetapkan.

3. Peneliti Selanjutnya

Pada penelitian ini hanya mengalisis tentang implementasi pendidikan akhlak, diharapkan untuk peneliti selanjutnya bisa menganalisis impelentasi pendidikan lainnya dan pada lembaga pendidikan yang lebih bagus untuk menambah keilmuan tentang kecerdasan spiritual.

4. Masyarakat 
Hendaknya ikut berpartisipasi dalam pendidikan karena masyarakat merupakan mitra sekolah yang mempunyai tanggung jawab terhadap pendidikan. Serta ikut berpartisipasi dalam melaksanakan pendidikan akhlak salah satunya dengan cara menjadi komite sekolah, dan lebih peduli akan pentingnya segala sesuatu yang berkaitan dengan pendidikan.

\section{DAFTAR PUSTAKA}

Abdullah, Yatimin. 2007. Studi Akhlak dalam Prespektif Al-Qur'an. Jakarta: Sinar Grafika Offset.

Anica. "Nilai-Nilai Pendidikan Karakter Dalam Surat Al-Ahzab Ayat 21 Perspektif Tafsir AlMishbah Karya Muhammad Quraish Shihab,” no. 13210035 (2017): 90.

Azmi, Muhammad. 2006. Pembinaan Akhlak Anak Usia Dini Pra Sekolah. Yogyakarta: Belukar.

Bungin, Burhan. 2008. Analisis Data Penelitian Kualitatif. Jakarta: Rajawali Press.

https://m.liputan6.com/regional/read/3250677/siswa-yang-pukul-guru-seni-hingga-tewas-dikenal$\underline{\text { sulit-ditebak }}$

Komsiyah, Indah. 2012. Belajar dan Pembelajaran. Yogyakarta: Penerbit Teras.

Majid, Abdul. 2007. Perencanaan Pembelajaran Mengembangkan Standar Kompetensi Guru. Bandung: Remaja Rosdakarya.

Marzuki. 2019. Pendidikan Karakter Islam. Jakarta: Amzah.

Sudarsono. 2005. Etika Islam tentang Kenakalan Remaja. Jakarta: PT Rineka Cipta.

Sudjana, Nana. 2001. Penelitian dan Penilaian Pendidikan. Bandung: Sinar Baru Argensindo, 2001.

Sufi, Marinda Nur Fauzi. 2018. "Implementasi Pendidikan Akhlak Melalui Program Full Day School dalam Menganggulangi Gaya Hidup Hedonisme". Tesis Tidak Diterbitkan. Malang, UIN Maulana Malik Ibrahim Malang. 